\title{
ORAÇÃO DE DESPEDIDA
}

\author{
Dra. Amália C. Carvalho
}

"Grande foi a perda que todos nós sofremos hoje. Ao externar a consternação de duas entidades às quais a Prof. a Glete de Alcântara enriqueceu com a sua simpatia e cultura, faço-o como companheira de trabalho na ABEn e como colega na EEUSP.

Nesta instituição, à qual pertenceu em duas épocas distintas, sua atuação foi sempre marcada pela dedicação ao ensino e pela preocupação constante em aperfeiçoar em seus alunos, o verdadeiro sentido de servir.

Sua volta, depois de aposentada da Escola que criou e organizou em Ribeirão Preto, sacrificando merecido repouso, demonstra seu apego à profissão que havia escolhido e o seu grande amor pelo magistério, e pela gente jovem, com a qual gostava de conviver.

Foi exemplo de trabalho, persistência, abnegação, companheirismo.

A Diretoria desta Escola, suas colegas, alunos e todos os funcionários choram sua perda. Nós do Departamento de Orientação Profissional, mais que todos os outros, sentiremos o vasio deixado pelo desaparecimento da chefe, colega e amiga.

Glete de Alcântara teve presença destacada na ABEn. Iniciou as atividades associativas asssim que regressou do Canadá onde se diplomou, em 1945; sua primeira atuação oficial foi em 1947, na Revista Brasileira de Enfermagem, como Secretária, no reinício de sua publicação aqui em S. Paulo. Desde então, nunca mais deixou de trabalhar para a Associação.

* 2. ${ }^{\text {a }}$ Vice Presidente da ABEn. 
Foi Presidente da Seção de S. Paulo no 2.0 biênio após sua organização, tendo sido reeleita para o biênio seguinte. Ao término do mandato foi eleita Presidente da ABEn e nessa qualidade presidiu a Comissão Executiva do Congresso Internacional de Enfermagem, o $1 .^{\circ}$ a realizar-se no Brasil, em 1953.

Exerceu a Presidência da Comissão de Educação durante 5 anos consecutivos. Já aposentada. aceitou novamente o pesado fardo de presidência da Associação, para o qual foi eleita em 1972. Desapareceu em meio a seu mandato, mas deixa a lição de uma vida dedicada à sua profissão e à sua associação de classe - uma vida dedicada ao próximo, pacientes, alunos, colegas. Deixa o exemplo de amor e dedicação ao trabalho, de combatividade nas lutas pelos seus ideais e pelos ideais das enfermeiras brasileiras, de entusiasmo pelas conquistas alcançadas, grandes ou pequenas.

Em nome da Diretoria desta Casa, de todas as colegas, dos membros do Departamento de Orientação Profissional, da Diretoria da ABEn e dos seus associados do Brasil inteiro, agradeço a lição e o exemplo. Que Deus guarde sua alma”. 


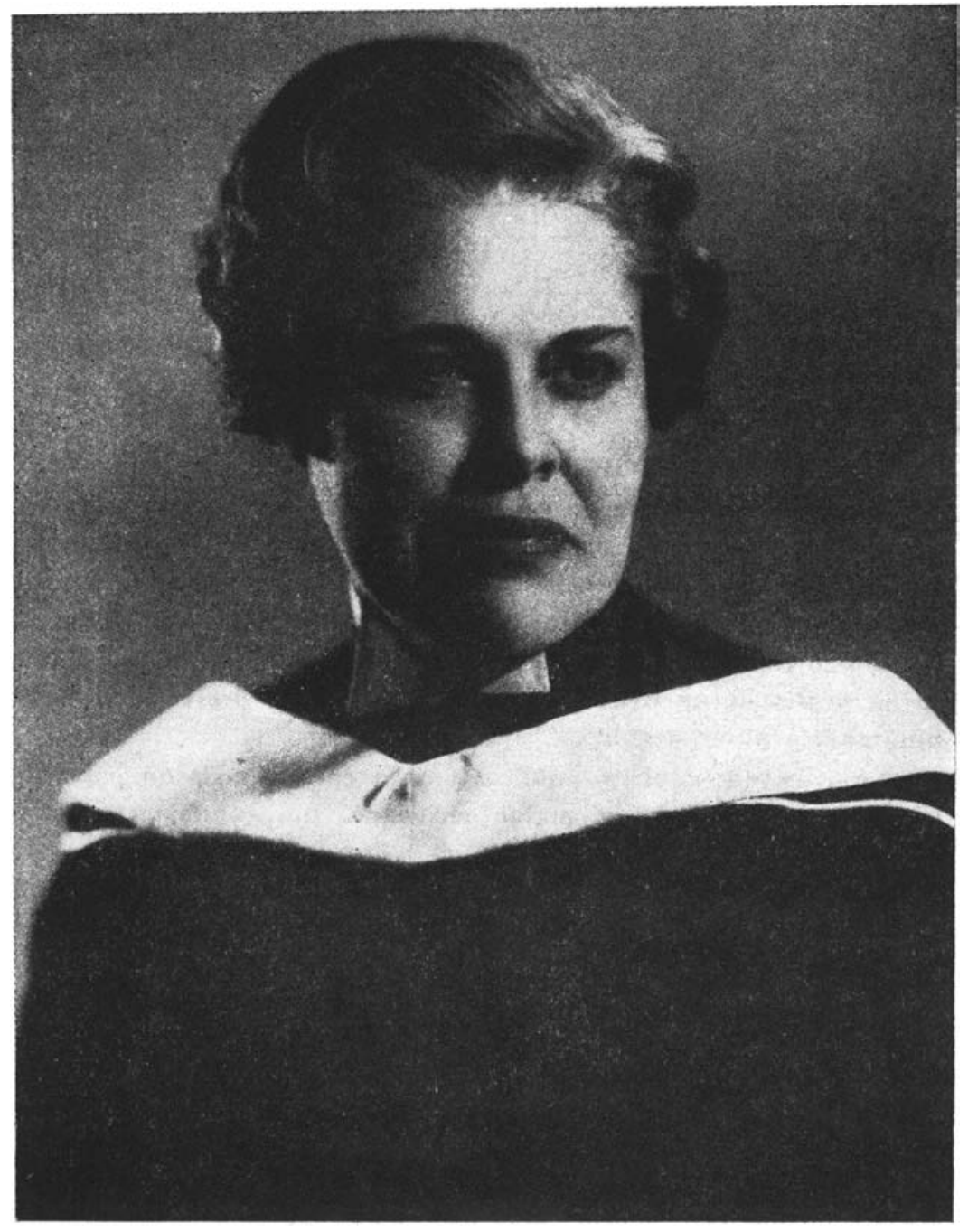

A ABEn perde sua Presidente - A Professora Dra. Glete de Alcântara, Presidente da ABEn, faleceu no dia 3 de novembro, após alguns meses de enfermidade. Seu corpo foi velado na Escola de Enfermagem da Universidade de São Paulo onde era professora de Ética e História da Enfermagem.

Após a Missa de Corpo Presente rezada por intenção de sua alma, a 2. ${ }^{a}$ Vice-Presidente da ABEn, Amália C. de Carvalho, proferiu a oração de despedida, em nome de ambas as instituições. EEUSP e ABEn. 